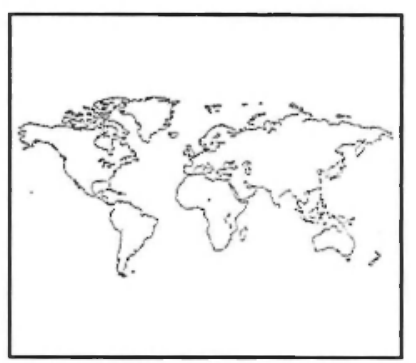

Robert Chambers is a Fellow of the Institute of Development Studies at the University of Sussex. He has worked on rural development in sub. Saharan Africa and SouthAsia and is currently concentrating on the development and spread of the approaches and methods of participatory rural appraisal. He is author of Rural Development: Putting the Last First, Longman, Harlow, 1983.

Address: The Institute of Development Studies, University of Sussex, Falmer, Brighton BN1 $9 R E$, UK, Fax: (44) 1273621202

1. This is a corrected and updated version of Poverty and Livelihoods: Whose Reality Counts? A Policy Paper No. 1 commissioned by UNDP for the World Summit for Social Devel-

\section{Poverty and livelihoods: whose reality counts?}

\author{
Robert Chambers
}

SUMMARY: This paper explores how professionals' universal, reductionist and standardized views of poverty differ from those of the poor themselves. Poverty line thinking concerned with income-poverty and employment thinking concerned with jobs, project Northern concerns on the South, where the realities of the poor are local, diverse, often complex and dynamic. Examples illustrate how poor people's criteria differ from those assumed for them by professionals. The paper also discusses neglected dimensions of deprivation including vulnerability, seasonality, powerlessness and humiliation. In the new understandings of poverty, wealth as an objective is replaced by wellbeing and "employment" in jobs by livelihood. The final sections argue for altruism and reversals to enable poor people to analyze and articulate their own needs, and they conclude with the implications for policy and practice of putting first the priorities of the poor.

\section{SUMMARY OVERVIEW(1)}

ANTI-POVERTY RHETORIC is widespread, and some indicators of human well-being have improved. However, current conditions are often appalling, trends in many places negative, and future prospects for hundreds of millions of people very bad.

In assessing conditions, and seeing what to do, professionals' realities are universal, reductionist, standardized and stable. Those of economists dominate, expressed in poverty thinking concerned with income-poverty, and employment thinking concerned with jobs. Both project Northern, more industrial and urban conditions, concerns and categories onto Southern, more agricultural and rural, realities. Both have force but miss much and mislead. Professional biases have been challenged but they remain deep, secure and distorting.

The realities of poor people are local, complex, diverse and dynamic. Income-poverty, though important, is only one aspect of deprivation. Participatory appraisal confirms many dimensions and criteria of disadvantage, ill-being and well-being as people experience them. In addition to poverty, these include social inferiority, isolation, physical weakness, vulnerability, seasonal deprivation, powerlessness and humiliation.

Sustainable livelihoods are an objective on which most poor people and professionals can agree. Household livelihood strat- 
opment, UNDP, New York, August 1994. It is also published as Discussion Paper 347 by the Institute of Development Studies, University of Sussex, Brighton BN1 9RE, UK. For insights into North-South, upper-lower relationships I am grateful to Jenny Chambers, and for comments on drafts of this paper to Rosalind Eyben, Simon Maxwell and Gunilla Olsson.
2. Chambers, Robert, and Gordon Conway (1992), Sustainable Rural Livelihoods: Practical Concepts for the 21st Century, Discussion Paper 296, Institute of Development Studies, University of Sussex, Brighton, UK, February, pages 9-12.

3. Normal professionalism and the new paradigm are elaborated on in Chambers, Robert (1993), Challenging the Professions: Frontiers for Rural Development, Intermediate Technology Publications, London, chapters $1,5,6$ and 8. egies often involve different members in diverse activities and sources of support, at different times of the year. Many of these, such as home-gardening, exploiting common property resources, share-rearing livestock, family splitting, and stinting are largely unseen by normal professionals. A sustainable livelihood intensive strategy stresses natural resources management. redistribution of livelihood resources, prices and payments, health, abolishing restrictions and hassle, and safety nets for poor people during bad times.

A paradigm of reversals and altruism demands a new professionalism. The paradigm and the new professionalism put people before things, and poor people and their priorities first of all. The challenges presented are institutional, professional and personal. The policy and practical means to promote and sustain well-being, livelihoods and equity include two complementary agendas, one conventional and one new. Underlying the new agenda is the basic human right of poor people to conduct their own analysis. Four elements in this new agenda are:

- Analysis and action by local people. especially the poor

- Sustainable livelihoods

- Decentralization, democracy and diversity

- Professional and personal change

Reversals and a radical rethink are required if the realities of the poor are to count.

\section{GLOSSARY OF MEANINGS}

MUCH CONFUSION, AND some false consensus, arises from vague and different uses of words. The senses in which some key words will be used in this paper are as follows:

- Deprivation refers to lacking what is needed for well-being. Its dimensions are physical, social, economic, political, and psychological/spiritual. It includes forms of disadvantage such as physical weakness, isolation, poverty, vulnerability and powerlessness.

- Development means good change.

- Employment means having a job with an employer who provides remuneration (usually a wage or salary) for work done. It does not include sporadic casual labour.

- Ill-being is the experience of bad quality of life.

- Income-poor and income-poverty refer to low per capita income.

- Livelihood refers to the means of gaining a living, including livelihood capabilities, tangible assets and intangible assets. ${ }^{(2)}$ Employment can provide a livelihood but most livelihoods of the poor are based on multiple activities and sources of food, income and security.

- Normal professionalism is the thinking, values, methods and behaviour dominant in a profession or discipline. ${ }^{(3)}$

- Paradigm means a coherent and mutually supporting pattern 
4. Chambers, Robert (1983), Rural Development: Putting the Last First, Longman, Harlow, pages 108-139.

5. Rosalind Eyben, personal communication.

6. This is a limited meaning for the purposes of this paper. The concept of sustainability applied to livelihood has much wider implications for rich as well as for poor. For a fuller definition, and exploration of the wider implications for the North as well as the South, see reference 2 .

7. Condensation of a speech to the Davos Development Conference, reported in the New York Times, 1 March 1992. of concepts, values, methods and action, amenable to wide application.

- Poor is allowed its common and imprecise usage. This goes beyond being the adjective for poverty, referring to lack of physical necessities, assets and income, to include the broader sense of being deprived, in a bad condition and lacking basic needs.

- Poverty refers to lack of physical necessities, assets and income. It includes, but is more than, being income-poor. Poverty can be distinguished from other dimensions of deprivation such as physical weakness, isolation, vulnerability and powerlessness with which it interacts. ${ }^{(4)}$

- Social development means "enhanced individual and community well-being and autonomy, within an integrated, equitable and just society". ${ }^{(5)}$

- Sustainable livelihood refers to a living which is adequate for the satisfaction of basic needs, and secure against anticipated shocks and stresses. ${ }^{(6)}$

- Vulnerability means not lack or want but exposure and defencelessness. It has two sides: the external side of exposure to shocks, stress and risk; and the internal side of defencelessness, meaning a lack of means to cope without damaging loss.

- Well-being is the experience of good quality of life.

Thus, well-being and ill-being refer more to experience, poverty more to physical lack, and deprivation to a much wider range of lacks and disadvantages.

"It is not that we should simply seek new and better ways for managing society, the economy and the world. The point is that we should fundamentally change how we behave," Vaclav Havel. ${ }^{(7)}$

\section{POVERTY AND LIVELIHOODS: WHOSE REALITY COUNTS?}

\section{a. Professionals and the Poor: Whose Reality Counts?}

THIS PAPER IS written as a challenge to all development professionals, including myself, and especially to those who prepare, take part in, and follow up on, the Social Development Summit. It asks: whose reality counts? The reality of the few in centres of power? Or the reality of the many poor at the periphery? It argues that these realities differ more than most professionals recognize. Insights into these differences and their implications are generating a new paradigm and a new and hopeful agenda. To recognize, accept, act on and evolve that new agenda is a personal, professional and institutional challenge, demanding deep change in the ways we think and behave. This requires altruism and reversals of much that is now normal. The Social Development Summit provides an opportunity for this change, for putting first the reality of the poor and making it count. Will the opportunity be recognized and seized? 
8. For a fuller balance sheet, see UNDP Human Development Report 1993 pages 12-13, and Adamson, Peter (1993), The Progress of Nations: the Nations of the World ranked according to their Achievements in Health, Nutrition, Education, Family Planning and Progress for Women, UNICEF, New York and subsequent publications in these series.

\section{b. The Context and Record}

For those weary of pedestrian reviews of the human condition, let me recommend skipping to the last paragraph of this section. Any normal balance sheet of development has to acknowledge achievements. According to the figures presented in Table 1, aggregate percentage improvements have been shown in some of the usual indicators of human well-being over recent decades. ${ }^{(8)}$

\section{Table 1: Reported Improvements in Indicators of Human Well-being in "Developing Countries"}

\begin{tabular}{l|cc|cr} 
& \multicolumn{2}{|c|}{$\begin{array}{c}\text { All developing } \\
\text { countries }\end{array}$} & \multicolumn{2}{c}{$\begin{array}{c}\text { Least developed } \\
\text { countries }\end{array}$} \\
\cline { 2 - 6 } & 1960 & 1992 & 1960 & 1992 \\
\hline Life expectancy & 46 & 63 & 39 & 50 \\
\hline $\begin{array}{l}\text { Infant Mortality per } \\
\text { 1,000 live births }\end{array}$ & 149 & 69 & 170 & 112 \\
\hline Adult literacy rate & 46 & 69 & 29 & 46 \\
\hline Real GDP per capita (US\$) & 950 & 2,730 & 580 & 880 \\
SOURCE: United Nations Development Programme (1994), Human Development \\
Report 1994, Oxford University Press, New York, Oxford, page 137.
\end{tabular}

Smallpox has been eradicated from the earth, and polio and guinea worm disease greatly reduced. In little more than a generation, the proportion of rural families with access to safe water is reported to have risen from less than 10 per cent to more than 60 per cent, and the proportion of children in primary school from less than one-half to more than three-quarters. Facts and figures like these can lull one into an impression of laudable achievement.

The downside of the record is, though, stark. Things are less bad than they would have been had nothing been done, and without the efforts of many organizations and individuals. But the glass that looks half full is also half empty; and as population grows the glass gets bigger. Averages conceal adverse income distribution and the condition of underclasses. Some economies are on a downward slide, especially where there is civil war. Malaria and tuberculosis spread again. HIV menaces whole peoples and economies with its insidious spread. Life expectancy in some countries has fallen, with civil disorder, famine and breakdown in government services. Nearly one billion people remain illiterate, and the primary school drop-out rate is 30 per cent. Some $\mathbf{4 0}$ million people are refugees or displaced within their countries. Globally, the number of people conventionally defined as in "absolute poverty" is often quoted as being over one billion, that is between one person in five and one in four. up from an estimated 800 million ten years ago (see Table 2).

Scholastic argument about figures will never end. The danger is that debate distracts from seeing what to do. Aggregation 
Table 2: One Estimate of Population Living in Absolute Poverty

\begin{tabular}{l|c|c} 
& $\begin{array}{c}\text { Number of } \\
\text { people (millions) }\end{array}$ & $\begin{array}{c}\text { Percentage of } \\
\text { total population }\end{array}$ \\
\hline Asia & 675 & 25 \\
\hline Sub-Saharan Africa & 325 & 62 \\
\hline Middle East and North Africa & 75 & 28 \\
\hline Latin America & 150 & 35 \\
\hline Total & 1,225 & 23
\end{tabular}

SOURCE: Kates, R.W. and V. Haarman (1992), "Where the poor live: are the assumptions correct?", Environment Vol.34, No.4, pages 4-28; citing "...the Worldwatch Institute's country estimates of absolute poverty and other social and economic indicators. Estimates should be viewed as midpoints in a range of plus or minus 10 per cent." These are the most recent comparative figures of this type that I have been able to trace, and probably refer to the late $1980 \mathrm{~s}$, since when there will have been changes.

and generalization are tempting and difficult but changes have occurred, as shown in Box 1.

These trends seem evident: that poverty, suffering and other deprivations are increasingly perceived as diverse; that conditions are moving in different directions in different countries, and for different groups of people; and that for hundreds of millions of people these have a downward momentum and are becoming worse. Poverty, suffering and deprivation seem to be becoming more regional, concentrated more in those countries which are least able to improve conditions. as in many in sub-

Box 1: Comparing 1990 with 1970, the poor are still concentrated in rural areas in Asia, but are:

\begin{tabular}{l|l} 
MORE LIKELY TO BE & LESS LIKELY TO BE \\
\hline African & Asian and Latin American \\
\hline $\begin{array}{l}\text { Children, urban women and, recently } \\
\text { in some regions. the elderly }\end{array}$ & Other adults \\
\hline Landless & Small farmers \\
\hline $\begin{array}{l}\text { Living in resource-poor areas } \\
\text { Urban }\end{array}$ & Living in well-endowed areas \\
\hline Refugees or displaced & Rural \\
\hline
\end{tabular}

SOURCE: Lipton, Michael and Simon Maxwell (1992), with assistance from J. Edstrom and H. Hatashima, The New Poverty Agenda: an Overview, IDS Discussion Paper 306, August. 
9. HIVIAIDS Pandemic 1993 Overview, Global Programme on AIDS, WHO, Geneva. There is much uncertainty about projections and locally, especially in parts of Africa, the impact is already devastating.
Saharan Africa; or in regions within countries, as with the three Indian states of Uttar Pradesh, Bihar and Madhya Pradesh with their combined population (1994) of over 300 million. As the scourge of HIV spreads, the hitherto localized impacts of AIDS deaths will soon be regional: 8 million AIDS related deaths are projected by the year 2000, ${ }^{(9)}$ the target year of "Health for All". In the longer term, the time bomb of HIV mocks development and makes a fantasy of much current debate about development. With AIDS, as in other ways, the South is more exposed and vulnerable, will suffer more, and will be far more devastated than the North.

Ill-being and early death take many forms; and those which are in the news - genocide and civil wars in Rwanda. Angola, the former Yugoslavia and elsewhere, and the denials of human rights as in Myanmar, Tibet, East Timor and many other places, all demand attention. But much more widely, less conspicuous ill-being and early death prevail. Much of it is hidden or taboo, as with the selective elimination, persecution and plight of females - foetuses, girls and women. The enormity of the abuse, sexual and other, of girl children, is still concealed everywhere by the sacred secrecy of the family. Worldwide, and with a concentration in South Asia, there are 110 million missing females, who would have been alive at the sex ratios of the industrial countries. These missing women almost total the (female and male) population of Pakistan, or four Canadas, or any two together of France, Iran, Italy, Turkey or the UK, or the combined population of Sudan, Kenya, Uganda, Tanzania, Malawi and Zambia. The scale of the discrimination, deprivation and suffering which underlie these figures beggars the imagination.

The scale and awfulness are the worse because, as never before, the powerful can see so much of what is happening and have power to act. The nightmare foreseen by C.P. Snow in 1959 has come about. Communications have brought us all dramatically closer and have made it easier and quicker to do things. Now we, the rich, sit in our warm rooms and comfy seats and watch the poor die on television, turning them on and off at will. Frequent viewing inoculates against compassion. There is more insight than ever before, accessible to those who want it, about how to enable poor people to do better, yet many of the same mistakes and misdemeanours persist at every level of interaction. There is more wealth in the world than ever before, and the peace dividend presents a windfall to give. Yet aid declines, and hundreds of millions of the poorest are on a downward slide, to become poorer and more vulnerable.

To those who read this paper, all this will be familiar, even boring. It has all been said before, and will be said again. And one wonders about the diverse and different realities behind the statistics. But in an overview paper, it seemed right to bow to convention by starting with statements such as these. The excitement comes when we ask whether anything has changed in our insights, and what we should and could now do.

The thrust of this paper is to see better what to do; development professionals have more power to change the world for the better than is normally realized. To grasp and use that power 
requires questioning conventional concepts and realities, exploring and embracing a new paradigm, adopting a new professionalism, empowering the poor to analyze and express their reality, and then putting that reality first.

\section{c. Professional Reality: Rhetoric and Concepts}

We are all part of a world system which perpetuates poverty and deprivation. Those who are poor and deprived do not wish to be poor and deprived. We who are well off and who have power say that poverty and deprivation are bad and should be reduced or eliminated. Yet, whatever else does not last, poverty and deprivation prove robustly sustainable. Why?

The usual reflex is to seek answers to this question by analyzing poverty and deprivation themselves. Papers on the poor proliferate, like this one. And there are many like me, who are not poor, willing to write about those who are. Papers on poverty are commissioned for conferences and roundtables, for symposia and summits. One may speculate on what topics the poor and powerless would commission papers if they could convene conferences and summits: perhaps on greed, hypocrisy and exploitation. But the poor are powerless and cannot and do not convene summits; and those papers are rarely written. It is not surprising: we do not like to examine ourselves. To salve our consciences we rationalize. Neo-liberalism paints greed as inadvertent altruism. The objects of development are, anyway, the poor, not us. It is they who are the problem, not us. We are the solution. So we hold the spotlight to them (from a safe distance). The poor have no spotlight to hold to us.

But poverty and deprivation are functions of polarization, of power and powerlessness. Any practical analysis has to examine the whole system: - "us", the powerful as well as "them" the powerless. Since we have more power to act, it is hard to evade the imperative to turn the spotlight round and look at ourselves.

In doing this, rhetoric and concepts can provide a starting point. Our views of the realities of the poor, and of what should be done, are constructed mainly from a distance, and can be seen to be constructed mainly for our convenience. We embody those views in the words and concepts which we use. Two which receive much prominence, and which are much stressed in the agenda for the Social Development Summit are poverty and employment. empirical critique see Beck Tony (1994), "Common property resource access by poor and class conflict in West Bengal", Economic and Political Weekly, January 22, pages 187-197; see also, Beck, Tony (1994), The Experience of Poverty: Fighting for Respect and Resources in Village India, Intermediate Technology Publications, London, especially chapters 1 and 8 .

11. Townsend, Peter (1993), The InternationalAnalysis of Poverty, Harvester Wheatsheaf, New York and London, page 3.

\section{d. Thinking about Income-Poverty}

"Poverty" is used in two main senses: in its first, common usage in development, it is a broad, blanket word used to refer to the whole spectrum of deprivation and ill-being; in its second usage, poverty has a narrow technical definition for purposes of measurement and comparison. ${ }^{(10)}$ In the words of one authority, "...'poverty' has to be given scientifically acceptable universal meaning and measurement. ${ }^{\text {(11) }}$ Poverty is then defined as low income, as it is reported, recorded and analyzed, or often as low consumption, which is easier to measure. This is the nor- 
12. Ahluwalia, Montek S. (1986), "Rural poverty, agricultural production, and prices: a reexamination" in Mellor, John W. and Gunvant M. Desai (editors), Agricultural Change and Rural Poverty: Variations on a Theme by Dharm Narain, Oxford University Press, Delhi, page 59.

13. Lipton, Michael and Martin Ravallion (1993), "Poverty and policy", monograph for Chapter 42 in Behrman, Jere and T.N Scrimivasan, Handbook of Development Economics Vol.3 North-Holland, Amsterdam. mal meaning of poverty among economists, and is used for measuring poverty lines, for comparing groups and regions, and often for assessing progress or backsliding within poverty in development. In this paper it is described as income-poverty.

In much professional discourse the narrow technical definition colonizes the common usage. Income-poverty starts as a proxy or correlate for other deprivations but then subsumes them. The classic pattern in erudite analysis is to start with a recognition that poverty is much more than income or consumption but then to allow what has been measured to take over and dominate. Thus, Montek Ahluwalia ${ }^{(12)}$ acknowledges that "...longevity, access to health and education facilities, and perhaps also security of consumption levels from extreme shocks" are equally relevant in analysis of poverty but points out that he is constrained because:

“..time series data on all of these dimensions are not available. Data from a series of consumption surveys conducted by the National Sample Survey Organization (NSS) are available, and these data have been used in most of the studies of rural poverty in India".

and which he then goes on to use.

Similarly, Lipton and Ravallion ${ }^{(13)}$ acknowledge the potential breadth of a definition of economic welfare, but then continue:

"While recognizing the limitations of the concept of 'economic welfare' as 'command over commodities', we will largely confine ourselves to that definition, in order to review the many important issues treated in the literature that has evolved around it."

The analysis is then narrowed because past discussion has been narrow.

What is recorded as having been measured, usually low consumption as a proxy for low income, then easily comes to masquerade in speech and prose as the much larger reality, a trap into which almost all fall, including the writer, from time to time. It is then but a short step to treating what has not been measured as not really real. Patterns of dominance are then reinforced: of the material over the experiential; of the physical over the social; of the measured and measurable over the unmeasured and unmeasurable; of economic over social values; of economists over disciplines concerned with people as people. It then becomes the reductionism of normal economics, not the experience of the poor, that defines poverty.

The pre-eminence of income-poverty seems wrong but it is understandable. Standing back, four reasons can be seen for its widespread acceptance and use as a measure and concept.

First, economists and their concepts still dominate the development discourse. There can be few multilateral or bilateral aid agencies, and few ministries of planning, where economists are not the most numerous profession (unless accountants). Economists' concepts, measures and methods are accepted as

Environment and Urbanization, Vol. 7, No. 1, April 1995 
the norm in much development practice and policy-making. This is not to undervalue the utility of economic concepts and methods. But it is to note that one way of seeing things prevails, and what is poverty to economists tends to become the normal meaning and measure for other disciplines and professions.

Second, income-poverty is a concept and measure generated and sustained in the cores of power, reflecting and reinforced by conditions in the rich industrial North. Poor people in the North have been mainly urban, in an industrial milieu, and have tended to rely on cash income, whether wages or social security payments: much of their economic status can then be captured in cash income or largely cash based consumption. Projecting and applying this Northern concept of poverty to the South assumes that similar conditions prevail.

Third, poverty defined as income-poverty or consumption-poverty is measurable. Non-monetary flows for subsistence or consumption can, in principle, be given monetary values and conflated into a single scale. This allows comparisons worldwide between the income. or more usually consumption, levels of different households, regions and nations. It also makes possible the measurement and assessment of poverty lines (meaning income-poverty or consumption-poverty lines). These provide time series measurements to show how income-poverty or consumption-poverty are changing, and so, how well a government can be presumed to be doing in the reduction of poverty in these senses. The utility of these measures for centrally placed professionals gives them a primacy and pride of place which tends to go unquestioned. What is measurable and measured then becomes what is real, and what matters, standardizing the diverse, and excluding the divergent and different.

Fourth, it is held that the worse-off people are, the more they are preoccupied with income and consumption, with the need to gain subsistence food and basic goods in order to survive. In a recent article, Martin Greeley argued for an income based concept of welfare, and that "...only when absolute poverty Imeaning absolute income-poverty] is no longer the core issue should our measure of development encompass a broader agenda of

14. Greeley, Martin (1994) "Measurement of poverty and poverty of measurement" in Davies, S. (editor), "Knowledge is power?", IDS Bulletin Vol.25, No.2, pages $50-58$

15. World Bank (1993), Poverty Reduction Handbook, World Bank, Washington DC, April. human need. ${ }^{n(14)}$ The worse the condition in which people find themselves, then the more justified is the economic reductionism of income-poverty; income-poverty reductionism becomes propoor.

Given these four factors and beliefs, it is not surprising to find that income-poverty has some primacy as a measure in the World Bank. A widely quoted statement by Lewis Preston, former President of the World Bank (in the foreword to the Poverty Reduction Handbook) illustrates this:

"Sustainable poverty reduction is the overarching objective of the World Bank. It is the benchmark by which our performance as a development institution will be measured. ${ }^{n(15)}$

The overarching objective is defined as something which will be measured - sustainable poverty reduction. The handbook elaborates on this thinking, giving primacy to the technical mean- 
16. World Bank (1990), World Development Report, Oxford University Press, Oxford.
17. FCO (1992), Foreign and Commonwealth Office including Overseas Development Administration, Departmental Report 1992, Cm 1902, HMSO, London, page 28. ing of poverty as income-poverty, which becomes the end or objective of development. Thus the preface states that "...investments in human resources help to increase incomes and reduce poverty" (my emphasis). The World Development Report 1990's approach to sustainable poverty reduction is, it says, twopronged, consisting of "...broadly based economic growth to generate efficient income-earning opportunities for the poor and improved access to education, health care and other social services so the poor can take advantage of these opportunities" (my emphasis). ${ }^{(16)}$ In this thinking, income is the end; improved access to education, health care and other social services are justified as means to that economic end. They are not presented here as justified ends in themselves or as a means to enhance capabilities or reduce suffering, or to increase self-respect, fulfilment or other human values (all hard to measure). Social development is a means not an end; the end is economic development.

That the World Bank makes sustainable poverty reduction (and not just being a good bank) its overarching objective is a matter for celebration. Nor should the narrowness and circularity of the thinking be cause for surprise in an organization which is called a bank, with many economists, and conditioned by the normal economic thinking. But Preston's quite simple statement contrasts with the more complex mission statement of the Overseas Development Administration, the British Government's aid agency. where social development advisers are relatively more numerous and influential:

"The aim of our overseas aid effort is to promote sustainable economic and social development and good government, in order to improve the quality of life and reduce poverty, suffering and deprivation in developing countries. ${ }^{n(17)}$

Going beyond economic development, to include social development and good government, and beyond reducing poverty, to improve the quality of life and reduce suffering and deprivation. embodies a much broader set of values.

Few would want to deny that measures of income-poverty have uses. They point to one dimension of inequality and inequity, between nations and within nations. But income-poverty is only one dimension among many, and it is suspect because it serves the needs of professionals in the cores of power rather than emerging from the realities of the poor at the peripheries.

\section{e. Thinking about Employment}

As with poverty, so with employment, the normal professional categories have been applied worldwide. Employment, unemployment, job, workplace and workforce are concepts and categories derived from urban industrial experience in the North. As with poverty, attempts have been made to impose and apply them in the South, including the rural and agricultural South. In his magisterial work on Asian poverty, a quarter of a century ago, Gunnar Myrdal agonized over the misleading preconception of Western economics as applied to Asian conditions: 
18. Myrdal, Gunnar (1968), Asian Drama: an Inquiry into the Poverty of Nations, Penguin Books, Harmondsworth.

19. See reference 18
"When new data are assembled, the conceptual categories used are inappropriate to the conditions existing: as, for example, when the underutilization of the labour force in the South Asian countries is analyzed according to Western concepts of unemployment, disguised unemployment and underemployment. The resulting mountains of figures have either no meaning or a meaning other than that imputed to them...The very fact that the researcher gets figures to play with tends to confirm his original, biased approach...the continuing collection of data under biased notions only postpones the day when reality can effectively challenge inherited preconceptions. ${ }^{\text {(18) }}$

And he called for behavioural studies founded on observations of the raw reality. ${ }^{(19)}$

Since Myrdal wrote the above, the informal sector has been discovered and explored, and livelihood has been proposed as a better word than employment to capture the complex and diverse reality of most of the poor. Indeed, livelihood is a larger, more universal and more useful concept for seeing what best to do, encompassing as it does for many of the poor so much more than the employment of a job, which for many is not and can not be a reality. Employment can rather be seen as a subset or component of livelihood.

Reductionist employment-thinking in terms of jobs is, though, not only alive and well but flourishing. The obsession in countries of the North and of elites in the South with employment and unemployment, which affects them and their families, has dominated much of the discussion and writing leading up to the Social Development Summit. In the background note for the Stockholm Roundtable of June 1994, the third section was entitled "Expansion of Productive Employment and Sustainable Livelihoods". But in the whole section, the word livelihood appeared only twice, in contrast with employment 28 times, unemployment 11, underemployment five, jobs six and workforce four times, all words and concepts derived from, and linked with, formal employment. Even more marked were the employment, industrial and urban biases of the major document debated at the Second Preparatory Committee for the Social Development Summit in New York in August 1994. In the 6,500 words of the third section, on "Productive Employment and the Reduction of Unemployment", livelihood appears only once but "jobs" features 13 times on one page alone; and the urban industrial bias is reflected in rural and agricultural concerns receiving only four paragraphs out of 48 .

Employment-thinking is deep rooted, and livelihood-thinking remains a marginalized orphan. The Society for International Development convened regional conferences on sustainable livelihoods as part of the run-up to the Social Development Summit but it is doubtful whether these will even ripple the mainstream. Whatever happens to the poor, full employment seems assured for normal economists and statisticians as they continue to analyze the available data on employment and unemployment, and to project their categories and concerns onto the raw and 
20. See, for example, this extract of a letter from Bob Lack, Auckland, New Zealand, printed in the Guardian Weekly, 5 September 1993: "So Prof Lester Thurow believes that real per capita GDP is the best overall measure of standard of living (August 22). May I respectfully disagree? If, after writing his article, Prof Thurow had eaten a healthy meal of home-grown vegetables, gone to bed, made love to his partner and then enjoyed a good night's sleep he would have contributed precisely nothing to GDP. If, on the other hand, he had driven to a casino, got drunk, crashed his car on the way home and injured himself and some passing pedestrians he would have increased his country's GDP by thousands of dollars. The fuel, the liquor, the tow truck and the ambulance, the car repairs and the hospital bills: all contribute to GDP and hence, by his reasoning, to the standard of living."

21. See annual reports from UNICEF State of the World's Children and from UNDP, Human Development Report and World Bank (1993), Social indicators of Development 1993, The Johns Hopkins Press, Baltimore MA, April.

22. United Nations Development Programme (1994), Human Development Report 1994, Oxford University Press, New York and Oxford, page 15.

23. With apologies to the IMF, the President of the United States, and the Secretary-General of the United Nations. rather different reality of most of the poor in the South. Myrdal would be sad to learn how little has changed.

\section{f. Offsetting Normal Professional Biases}

Efforts have been made to offset the biases towards the income measure of poverty and deprivation, and towards an employment measure of livelihood. Those offsetting income-poverty are well known. The World Bank's World Development Reports, since their inception, have ranked countries according to per capita GDP. However, the weak relationship between per capita GDP and human well-being is commonplace. Income distribution is critical. Much of the good life is uncounted in GDP (friendship, love, story-telling, self-sacrifice, laughter, music, health, creativity...) and much of the bad life adds to it (insurance claims, security guards, fossil fuel consumption, cutting down forests...).(20) Very different perspectives have been given by UNICEF's annual State of the World's Children which ranks countries according to their under-five mortality rates; by the Physical Quality of Life Index (PQLI) which combines in a single scale life expectancy at one year, adult literacy and infant mortality; the Human Development Index (HDI) of UNDP's annual Human Development Report which combines per capita GDP, life expectancy ai birth, and literacy; and by the World Bank itself, with its Social Indicators of Development (1993) which lists poverty indicators such as public expenditure on social services, immunization, and fertility rates. ${ }^{(21)}$

All these show up weaknesses in the correlations between income-poverty and some other deprivations. Strikingly, the latest Human Development Report shows Sri Lanka, Nicaragua, Pakistan and Guinea all with per capita incomes in the US\$400500 range but with life expectancies of, respectively, $71,65,58$ and 44 , and infant mortality rates of, respectively, 24, 53, 99 and 135. ${ }^{(22)}$ Whatever the criticisms of these measures and scales, they have been useful for comparisons and for forcing reflection on priorities.

Efforts to offset the bias towards employment measures are less developed. Livelihoods are harder to measure than mortality rates, life expectancy or literacy. So they are treated as less real. Labour intensive growth as an objective is designed to increase employment and may indeed do so. But it is not the same as sustainable livelihood intensity where livelihoods depend on a multiplicity of activities and resources.

The root problem is that professionals and poor people seek, experience and construct different realities. Some contrasting tendencies are summarized in Table 3.

The view from on high seeks and sees sameness and simplifying stereotypes.

The World Bank, highest of us all Looks down to see poor people small Like atoms all, a shape and size

For which it's right to standardize. ${ }^{(23)}$ 


\section{Table 3: Contrasting Tendencies in Professionals' and Poor People's Realities}

\begin{tabular}{l|l} 
PROFESSIONALS & POOR PEOPLE \\
\hline Universal & $\begin{array}{l}\text { local, specific } \\
\text { complex } \\
\text { Simplified }\end{array}$ \\
Reductionist & holistic \\
Standardized & experiential \\
Physical & unquantified \\
Guantified & multi-dimensional deprivation \\
Income-poverty & livelihood \\
Employment &
\end{tabular}

The question is whether concepts and measures that are universal, standardized, measurable, generated by and designed for conditions in the urban industrial North can be universally applied in the more rural and agricultural South, and whether they fit or distort the diverse and complex realities of most of the poor.

\section{THE REALITIES OF THE POOR}

A PERSON WHO is not poor who pronounces on what matters to those who are poor is in a trap. Self-critical analysis, sensitive rapport, and participatory methods can contribute some valid insight into the values, priorities and preferences of poor people. We can struggle to reconstruct our realities to reflect what poor people indicate to be theirs. But there will always be distortions. We can never fully escape from our conditioning. And the nature of interactions between the poor and the nonpoor affect what is shared and learnt. In what follows, however much I try, I cannot avoid being wrong in substance and emphasis. For I am trying to generalize about what is local (and both rural and urban), complex, diverse, dynamic, personal, and multidimensional, and to do this from scattered evidence and experience, perceived, filtered and fitted together inevitably in a personally idiosyncratic way. Error is inherent in the enterprise. There must always be doubts. But if the reality of poor people is to count more, we have to dare to try to know it better.

Help comes from field researchers, especially social anthropologists, from those who have been lacilitating new participatory methods of appraisal, and increasingly from poor people themselves. The new methods enable poor people to analyze and express what they know, experience, need and want. They bring to light many dimensions of deprivation, ill-being and wellbeing, and the values and priorities of poor people. Three sets of findings provide illustrative insights:

1. Jodha's Paradox: Income-poorer but better off: Jodha asked farmers and villagers in two villages in Rajasthan for their 
24. Jodha, N.S. (1988), "Poverty debate in India: a minority view" Economic and Political Weekly, Special Number, November, pages 2421-2428. own categories and criteria of changing economic status. ${ }^{(24)}$ They named 38 criteria. Comparing data from his fieldwork in 1964-66 with 1982-84 he found that the 36 households which were more than 5 per cent worse off in per capita real incomes were on average better off according to 37 out of their own 38 criteria. (The one exception was consumption of milk, more of which was being sold outside the village). The improvements included quality of housing, wearing shoes regularly, less dependence in the lean season, and not having to migrate for work (see Table 4). Several of the criteria reflected more independence.

\section{Table 4: Indicators of Well-being in Two Rajasthan Villages, of Households whose Per Capita Real Income declined 5 per cent or more over Two Decades}

\begin{tabular}{l|c|c} 
& \multicolumn{2}{|c}{$\begin{array}{c}\text { Percentage of the } \\
\text { 36 households }\end{array}$} \\
\cline { 2 - 3 } & $\mathbf{1 9 6 3 - 6}$ & $\mathbf{1 9 8 2 - 4}$ \\
\hline With one or more members working as attached or semi-attached & 37 & 7 \\
\hline Residing on patron's land or yard & 31 & 0 \\
\hline Taking seed loans from patrons & 34 & 9 \\
\hline Taking loans from others besides patrons & 13 & 47 \\
\hline Marketing farm produce only through patrons & 86 & 23 \\
\hline With members seasonally out-migrating for job & 34 & 11 \\
\hline $\begin{array}{l}\text { Selling over 80 per cent of their marketed produce during the } \\
\text { post-harvest period }\end{array}$ & 100 & 46 \\
\hline Making cash purchases during slack-season festivals etc. & 6 & 51 \\
\hline With adults skipping third meal in the day during the summer & 86 & 20 \\
\hline scarcity period) & 0 & 86 \\
\hline Where women and children wear shoes regularly & 91 & 34 \\
\hline With houses with only impermanent traditional structure & 6 & 52
\end{tabular}

SOURCE: Jodha, N.S. (1988), "Poverty debate in India: a minority view", Economic and Political Weekly, special number, November, pages 2421-2428.

The reality which these income-poorer villagers presented to Jodha contrasts with a normal economist's reality. They were income-poorer and so, in an economist's terms, worse off; but in their own terms they were, on average, much better off.

2. Findings from Participatory Analysis: Analysis by local people using participatory rural appraisal (PRA) methods has shown similar outcomes. In a PRA process in a Pakistan village in April 1994:

"...the local people did a matrix on their existing sources of income to determine the preferred income source. Interestingly, for me, the criterion 'more income' was the ninth or 
25. Personal communication Rashida Dohad.

26. Grandin, Barbara (1988), Wealth Ranking in Smallholder Communities: a Field Manual Intermediate Technology Publications, London.

27. See: Mukherjee, Neela (1992), "Villagers' perceptions of rural poverty through the mapping methods of PRA", RRA Notes 15, May, pages 21-26; Sarch, Marie-Therese (1992), "Wealth-ranking in the Gambia: which households participated in the FITT Programme?", RRA Notes 15, May, pages 14-20; Schaefer, Stephanie S. (1992), "The 'beans game' - experiences with a variation of wealth-ranking in the Kivu region, Eastem Zaire", RRA Notes 15, May, pages 2728 ; and Rajaratnam, J., personal communication. tenth one listed (out of a total of about 20 criteria). 'More time at home', 'ability to get involved in neighbours' joys and sorrows' were listed earlier...the generally perceived-to-bepreferred source of income (high-paying skilled/manual labour in the Middle Eastern countries, particularly Dubai) did not emerge as victor..., the reason worked out by the local analysts being that it did badly on their social criteria. ${ }^{n(25)}$

Diverse criteria have also emerged from well-being ranking, one of the methods of PRA. In an economic tradition, "wealth" was originally the criterion by which local people were asked to card sort the households in their community. ${ }^{(26)}$ Repeatedly, when outsider facilitators have tried to focus discussion and ranking on wealth, local people have insisted on using a wider range of criteria as contributing to their concepts of well-being and ill-being, of the good and bad life. ${ }^{(27)}$ Health and physical disability feature strongly. A range of criteria from various sources is presented in Box 2.

Box 2: A short illustrative list of some criteria used by local people in well-being grouping and ranking: a selection from sources in Asia and sub-Saharan Africa (expressed here in the negative form).

- Disabled (e.g. blind, crippled, mentally impaired, chronically sick)

- Widowed

- Lacking land, livestock, farm equipment, grinding mill

- Cannot decently bury their dead

- Cannot send children to school

- Having more mouths to feed, fewer hands to help

- Lacking able-bodied members who can fend for their families in the event of crisis

- with bad housing

- Having vices (e.g. alcoholism)

- Being "poor in people", lacking social supports

- Having to put children in employment

- Single parents

- Having to accept demeaning or low status work

- Having food security for only a few months each year

- Being dependent on common property resources

SOURCES: include Sarch, M.T. (1992), "Wealth-ranking in the Gambia: which households participated in the FITT programme?", RRA Notes 15, May, pages 14-26; also Redd Barna (1993), Not Only the Well-off but also the Worse-off, Report of a Participatory Rural Appraisal Training Workshop, 4-22 October 1993, Chiredzi, Zimbabwe, Redd Barna Regional Office Africa Training and Development, PO Box 12018, Kampala, Uganda; and A. Rajaratnam and J. Rajaratnam personal communication 1993.

3. Participatory Poverty Assessments: The World Bank has been breaking new ground in its poverty assessments. In the words of Sven Sandstrom these are designed:

Enviror mert and Urbanization, Vol. 7, No. 1, April 1995 
8. Sandstrom, Sven (1994) "The learning curve", in Boer, Leen and Jaap Rooimans (editors), The World Bank and Poverty Reduction, contributions to a seminar, The Hague, November 17, 1993. Ministry of Foreign Affairs, Development Cooperation Information Department, The Hague.

29. Norton, Andy, Dan Owen and J.T. Milimo (1994), Zambia Participatory Poverty Assessment, Volume 4 of Zambia Poverty Assessment, World Bank, Washington $\mathrm{DC}$.
30. The Ministry of Health acted quickly and already in 1994 had initiated a training programme for health staff (personal communication, Dan Owen).
31. Frankl, Viktor (1978), The Unheard Cry for Meaning: $P$ sychotherapy and Humanism, Simon and Schuster, New York. "to help us to address three fundamental issues: Who is poor? Why are they poor? What needs to be done to reduce the number of the poor? ${ }^{n(28)}$

The Participatory Poverty Assessments (PPAs) conducted under the auspices of the World Bank in Ghana, Zambia, Kenya and some other countries now have the potential for going beyond these questions, to ask: Who defines poverty? Who are the poor as defined within a society by local people themselves? What criteria of poverty or deprivation do they have? What are their priorities? The PPA sponsored by the World Bank in Zambia, using participatory rural appraisal techniques, gave insights into conditions, trends and poor people's priorities with practical implications. ${ }^{(29)}$ To illustrate some of the range:

- Health was repeatedly and consistently given a higher priority than education. Indeed, education was not raised as a priority need in most communities.

- Payment of school fees was found to be required at the most difficult time of the year, coinciding with food shortages, heavy work in agriculture, indebtedness, expenditures for Christmas and high incidence of disease.

- The rude behaviour of health staff was a deterrent to poor people going for treatment.

- Food-for-work at bad times was highly valued.

- All-weather roads were desired not only for marketing but also to give access to clinics and hospitals during the rains.

- Mangoes are good because they provide food at the worst times of the year.

Insights such as these indicate actions - postponing school fee payments, training health staff to be more caring, ${ }^{(30)}$ foodfor-work for all-weather roads, improving and spreading mangoes and similar tree food crops - with high benefits in poor people's own terms for relatively low financial costs.

\section{DIMENSIONS OF DEPRIVATION}

THESE AND OTHER examples illustrate the multi-dimensionality of deprivation and disadvantage as poor people experience them. Deprived people are often thought of as being uniform. The "rural masses" commonly expresses a stereotype. But. if anything, there is more diversity among the poor than among the non-poor. Under extreme deprivation, as Viktor Frankl found in his study of inmates of concentration camps, people react in sharply different ways. ${ }^{(31)}$ Disadvantage itself takes many forms. Any list of dimensions will be provisional and personal. The eight which follow are an attempt to capture some of poor people's reality, but can surely be improved upon.

The first three are among the better recognized dimensions of deprivation:

1. Poverty refers to lack of physical necessities, assets and income. It includes but is more than being income-poor. Pov- 
erty can be distinguished from other dimensions of deprivation such as physical weakness, isolation, vulnerability and powerlessness.

2. Social inferiority can be ascribed, acquired or linked with age and lifecycle. It can be socially defined as genetically inferior or disadvantaged, including gender, caste, race and ethnic group, or being "lower" in terms of class, social group or occupation, or linked with age, as with children and sometimes daughters-in-law.

3. Isolation refers to being peripheral and cut off. Poor people can be isolated geographically - living in a "remote" area; isolated in communication, lacking contacts and information, including not being able to read; isolated by a lack of access to social services and markets; and isolated by a lack of social and economic supports.

Five other dimensions, prominent in the realities of the poor and weak, have been relatively neglected by the development professions:

4. Physical weakness: Disability, sickness, pain and suffering are bad in themselves. Beyond this, the body is for many their major resource. Professionals, dependent as they are on their brains more than their bodies, tend to undervalue the importance to many of the poor of the asset of a fit strong body and the liability of a body which is sick, weak or disabled. Repeatedly, in defining ill-being and well-being, poor people mention physical weakness, sickness or disability, both as bad in themselves and in their effects on others. Having a household member who is physically weak, sick or handicapped, unable to contribute to household livelihood, but needing to be fed and cared for, is a common cause of income-poverty and deprivation

32. Evans, Timothy (1989), "The impact of permanent disability on rural households: river blindness in Guinea", IDS Bulletin Vol.20, No.2, April, pages 41-48.

33. Helander, Einar (1993), Prejudice and Dignity: an Introduction to Community Based Rehabilitation, UNDP Division for Global and Interregional Programmes, New York, page 5. as graphically shown for river-blindness ${ }^{1321}$ and now spreading widely in new forms with AIDS. The prominence of disability in the consciousness of poor people in the South is shown by the frequency with which, in participatory social mapping, village analysts spontaneously represent the disabled as a category. Those who are sick are the concern of health services. Those who are otherwise disabled are numerous, yet neglected. There are perhaps 200 million disabled persons in the South ${ }^{(33)}$, and probably more than another 200 million adversely affected and impoverished through having to support the disabled. Yet the 1993 UNDP Human Development Report does not include disability in any of its tables. The disabled are among the most unseen and politically powerless, and not only in the South.

5. Vulnerability: Much prose uses "vulnerable" and "poor" as alternating synonyms. But vulnerability is not the same as income-poverty or poverty more broadly defined. It means not lack or want but exposure and defencelessness. It has two sides: the external side of exposure to shocks, stress and risk; and the internal side of defencelessness, meaning a lack of means to cope without damaging loss. Loss can take many forms - becoming or being physically weaker, economically impoverished, socially dependent, humiliated or psychologically harmed.

For hundreds of millions, vulnerability has increased and so their livelihoods have become less securely sustainable even 
34. Woolf, Leonard (1991), "The village in the jungle" in Gill, G.J., Seasonality andAgriculture in the Developing World: a Problem of the Poor and Powerless, Cambridge University Press.

35. Hirway, Indira (1986), Abolition of Poverty in India with Special Reference to Target Group Approach in Gujarat, Vikas Publishing House, New Delhi, pages $142,144,147$ when their incomes have risen. In most cultures and contexts, patron-client safely nets have weakened, the extended family gives less support, contingencies such as weddings, funerals, brideprice and dowry have become more costly, and effective health services have become less accessible or more expensive or both. More people have moved into insecure environments. More people live exposed to the risks of famine, flood. storm. and some human, crop and animal diseases, than before. War and civil disorder remain widespread. And where there have been past disasters, many are more vulnerable through the earlier loss of livelihood assets and means to cope. It then takes less to make a famine, as in the current 1994 famine in Ethiopia.

For poor people there are often trade-offs between income and security. Income-poverty thinking can neglect vulnerability in seeking to raise incomes. On a huge scale, the Integrated Rural Development Programme in India provides subsidized loans to poor people to acquire assets aimed at raising their incomes. But, as many have experienced, this increases vulnerability: loss of the asset can lead to debt and being worse off than before. At the margin, poor people often prefer a lower income with less risk of debt and dependence.

6. Seasonality: The seasonal dimensions of deprivation are under-perceived by professionals who are urban based and season proofed. Yet, in tropical seasonality. many adverse factors for the poor often coincide during the rains - hard agricultural work, shortage of food, scarcity of money, indebtedness, sickness, the late stages of pregnancy and diminished access to services; and indicators such as birthweights, body weights, infant mortality and morbidity all bear this out. In the words of a mother in a novel about Sri Lanka:

“I say to the father of my child, 'Father of Podi Sinho,' I say, There is no kurrakan in the house, there is no millet and no pumpkin, not even a pinch of salt. Three days now and I have eaten nothing but.jungle leaves. There is no milk in my breasts for the child.' Then I get foul words and blows. 'Does the rain come in August?' he says. 'Can I make the kurrakan flower in July? Hold your tongue, you fool.' August is the month in which the children die. What can I do? ${ }^{m(34)}$

7. Powerlessness: The poor are powerless. Dispersed and anxious as they are about access to resources, work and income, it is difficult for them to organize or bargain. Often physically weak and economically vulnerable, they lack influence. Subject to the power of others, they are easy to ignore or exploit. Powerlessness is also, for the powerful, the least acceptable point of intervention to improve the lot of the poor.

8. Humiliation: Self-respect, with freedom from dependence, is perhaps the dimension most overlooked and undervalued by professionals. Indira Hirway in Gujarat found that poor people disliked taking on debts because what followed from them included "abuses and insults", "helplessness, insults and pain", and "touching the feet of the lenders and swallowing insults and abuses". (35) Jodha (see Table 4 above) grouped several of

Environment and Urbanization, Vol. 7, No. 1, April 1995 
the criteria of economic well-being he was given by villagers as not being subject to "indispensability of patron's (rich people's) support/mercy/patronagen. These criteria included not residing on the patron's land, not taking seed loans from patrons, not taking loans only from patrons and not marketing produce only through patrons. When Beck asked very poor people in three villages in West Bengal "Which do you value more, food or self-respect. 49 out of 58 said they valued self-respect more, three valued each equally and only six put food first. ${ }^{(36)}$ Typically, one replied "If I don't have self-respect, will food go into the stomach?" Beck concluded that "Despite their regular hunger, most poorest people in the study villages felt it was more important to be treated with respect than gratify immediate needs." It was his view that "If this feeling is widespread among the poor in India, then planners' and academics' exclusive interest in income and nutrition is inadequate for understanding poverty". ${ }^{(37)}$ But humiliation and self-respect do not lend them-

37. Beck, Tony (1989), "Survival strategies and power among the poor in a West Bengal village" in "Vulnerability: how the poor cope", IDS Bulletin Vol.20, No.2, pages 23-32.

38. In this paper I am not treating conflicts of values. Suffice it to say that the playing field is not level. I feel free to criticize female genital mutilation or dowry but am affronted when a poor person asks me how much my salary is.

39. For an elaboration of sustainable livelihoods as a concept, see Chambers, Robert (1987), "Sustainable livelihoods, environment and development: putting poor rural people first", Discussion Paper 240, Institute of Development Studies, University of Sussex, Brighton, UK (out of print, available from the author); also Conroy, Czech and Miles Litvinoff (editors) (1988), The Greening of Aid: Sustainable Livelihoods in Practice, Earthscan, London: Bernstein, Henry, Ben Crow and Hazel Johnson (editors) (1992), Rural Livelihoods: Crises and Responses, Oxford University Press in association with the Open University; see also reference 2 . Together with basic rights, sustainable livelihoods are being debated and adopted by OXFAM as part of the theoretical and practical basis of their work. selves to measurement, are in practice not measured and so, for normal professionals, barely exist and rarely count.

Deprivation and well-being have, then, many dimensions. Poor people have many priorities. What matters most to them often differs from what outsiders assume, is not always easy to meas ure, and may not be measurable at all. If poor people's realities are to come first, development professionals have to be sensitive, have to decentralize and empower, to enable poor people to conduct their own analysis and express their own multiple priorities.

There remain deep dilemmas over "our" knowledge and values $^{(38)}$ and "theirs". Our knowledge has an advantage with the physical universe and with whatever is microscopic, macroscopic, large-scale or distant from where poor people live. In these domains we are empowered by our linked communications, instruments and science. But their knowledge has an advantage with the local, the social, whatever is continuously observed and experienced, and whatever close to them touches their lives and livelihoods; and they are the only experts on their life experiences and priorities. But our power in the past has overwhelmed their knowledge, hidden their analytical abilities and allowed us to assume that we know what they experience and want. The problem is one of balance between two realities - ours which is powerful and theirs which is weak. Standing back and standing down, we need to search for overlaps where their realities and aspirations can give rise to practical concepts which we can then use to help empower them.

\section{SUSTAINABLE LIVELIHOODS}

ONE SUCH OVERLAP is suggested by sustainable livelihoods. (39) For many of the poor, livelihood seems to fit better than employment as a concept to capture how poor people live, what their realistic priorities are, and what can help them. "Sustainable" then refers to the longer-term and "livelihood" to the many activities which make up a living.

On sustainability, it is a common prejudice among those who 
40. Hartmann, Betsy and James Boyce (1983), Quiet Violence: View from a Bangladesh Village, Zed Press, London.

41. De Waal, A. (1989), Famine That Kills, Clarendon, Oxford; also De Waal, A. (1991), "Emergency food security in Western Sudan: what is it for?" in Maxwell, Simon (editor), To Cure All Hunger: Food Policy and Food Security in Sudan, Intermediate Technology Publications, London.

42. For example, Corbett, Jane (1988), "Famine and household coping strategies", World Development Vol.16, No.9, pages 1099-1112. are not poor that poor people inherently "live hand-to-mouth" and take the short-term view. But, in practice, again and again, they show tenacity and self-sacrifice in trying to take the longterm view and safeguarding the basis for their livelihoods. Small farmers with secure rights invest their labour in land-shaping, terracing and creating fertile micro-environments; in harvesting water, silt and nutrients; and in planting and protecting trees. A desperately poor family in Bangladesh only cut down their two trees as a near last resort. ${ }^{(40)}$ Alex de Waal (pers. comm.) found a woman in Darfur in Sudan, on leaving her village in a famine, preserving millet seed for planting on her hoped-for return by mixing it with sand to prevent her hungry children eating it. On the basis of extended fieldwork during famine, he concluded that "...avoiding hunger is not a policy priority for rural people faced with famine", and "...people are quite prepared to put up with considerable degrees of hunger, in order to preserve seed for planting, cultivate their own fields or avoid having to sell an animal. ${ }^{\text {(41) }}$ It is now a widespread finding that, as soon as food shortage threatens, poor people eat less and worse in order to protect their livelihood assets in the bad times to come. ${ }^{(42)}$ It is less the poor, and more the outsiders, who take the short-term view - contractors who cut the forest. officials fixated on the financial year and politicians who cannot see beyond the next election.

On livelihoods, the strategies of the poor are usually diverse and often complex. They can be compared to those of hedgehogs and foxes, after the saying of Archilochus that "The fox has many ideas but the hedgehog has one big idea". Full-time employees in the industrial world and industrial sectors are hedgehogs, with one big idea, a single source of support. Those poor people, often powerless, desperate or exploited, who have or can have but one survival strategy are the same - slaves, bonded labourers, outworkers tied to single supplier-buyers, beggars, some vendors, prostitutes and some other occupational specialists. But most poor people in the South, and more now in the North, are foxes with a portfolio of activities, with different members of the family seeking and finding different sources of food, fuel, animal fodder, cash and support in different ways in different places at different times of the year. Their living is improvised and sustained through their livelihood capabilities, through tangible assets in the form of stores and resources, and through intangible assets in the form of claims and access (see Figure 1).

Fox strategies are rarely fully revealed by conventional questionnaire surveys. Schedules construct a standardized, short and simple reality, and investigators' incentives are to record less, not more. Much that matters is liable to be left out. As the authors of the 1994 Participatory Poverty Assessment for Zambia put it:

"Many aspects of rural livelihoods are not captured in either income or consumption based survey data. This is because they are neither commoditized nor evident enough to the researchers to be allocated 'imputed values'... Energy (fuelwood) and herbal medicines are two examples. A significant element of the 'safety net' for many rural people in 
43. See reference 29, page 93 .

44. For example, see reference 37. See also Breman, Jan (1985), Of Peasants, Migrants and Paupers: Rural Labour Circulation and Capitalist Production in West India, Oxford University Press, Delhi, Bombay, Calcutta, Madras; Davies, Susanna (1993), Versatile Livelihoods: StrategicAdaptation to Food Insecurity in the Malian Sahel, Institute of Development Studies, University of Sussex, February; Griffith, Geoff (1994), Poverty Alleviation for Rural Women, Avebury, Aldershot, UK; Gulati, Leela (1981). Profiles in Female Poverty: a Study of Five Poor Working Women in Kerala, Hindustan Publishing Corporation (India), Delhi; Hirway, Indira (1986), Abolition of Poverty in India with Special Reference to Target Group Approach in Gujarat, Vikas Publishing House, New Delhi; Rahmato, Dessalegn (1987), "Peasant survival strategies", in Angela Penrose (editor), Beyond the Famine: an Examination of the /ssues behind Famine in Ethiopia, International
Figure 1: Components and Flows in a livelihood

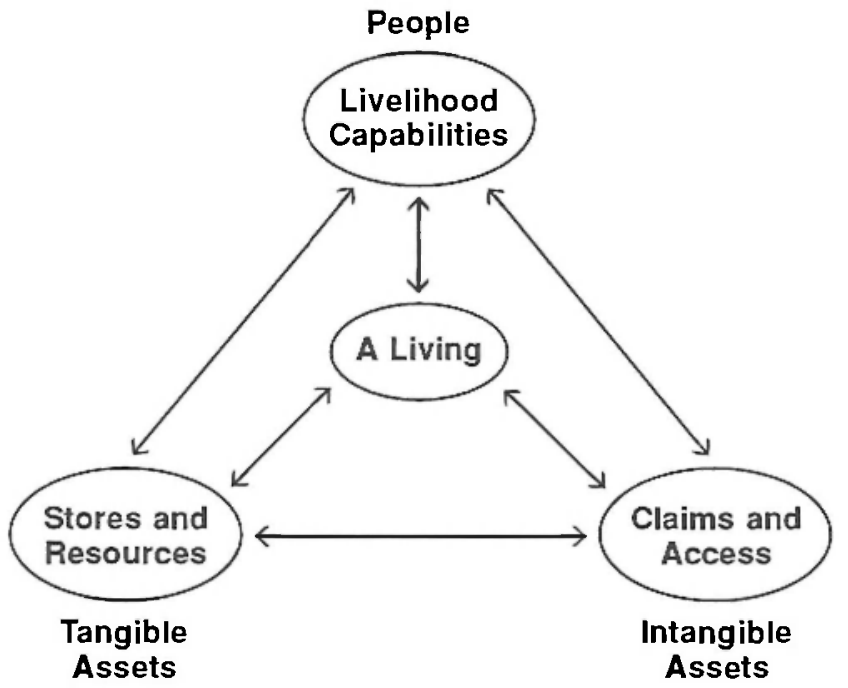

times of stress consists of 'famine foods' which can be gathered from bush and fallow lands...". (43)

The ingenuity and opportunism of poor people, and the diversity and complexity of their strategies, can be illustrated by case studies and the accounts of social anthropologists and others. ${ }^{(44)}$ Even within the same village, different social groups of the landless can have completely different strategies. ${ }^{(45)}$ Strategies and sources of food, income, support and survival include:

- Home-gardening: (Both rural and urban) and the exploitation of micro-environments. Six studies in Indonesia reported the proportions of household income deriving from home gardens as variously 10-30, 20-30, over 20,22-33, 41-51 and 42-51 per cent, while another Indonesia study found the proportion higher among the poor, providing 24 per cent of their income compared with 9 per cent for the well off. ${ }^{\text {(46) }}$

- Common property resources (CPRs): Fishing, hunting, grazing, and gathering in lakes, ponds, rivers, the sea, forests, woodlands, swamps, savannas, hills, wastelands, roadsides.... for any of a vast range of fish, animals, fodders, wild foods, fibres, building materials, fuel, fertilizer, medicines and much else. CPRs are often a major source of livelihood for the poor: in his study of the poorest in three villages in West Bengal, Beck estimated that CPRs accounted for between 19 and 29 per cent of the household's income. ${ }^{(47)}$ From his extensive study of CPRs in India, Jodha concluded that, in general, the rural poor obtained the bulk of their fuel supplies and fodder from CPRs and that CPRs, though likely to be underestimated, accounted for 14 to 23 per cent of their household incomes. ${ }^{(48)}$ 
Institute for Relief and Development, Food for the Hungry International, Geneva.

45. For example, Heyer, Judith (1989), "Landless agricultural labourers' asset strategies", IDS Bulletin Vol.20, No.2, pages 3340.

46. Hoogerbrugge, Inge D. and Louise O. Fresco (1993), Homegarden Systems: Agricultural Characteristics and Challenges, Gatekeeper Series No.39, International Institute for Environment and Development, London, page 12.

47. See reference 10 , page 10

48. Johda, N.S. (1991), Rural Common Property Resources: a Growing Crisis, Gatekeeper Series No.24, International Institute for Environment and Development, London.

49. See reference 2; also Swift, Jeremy (1989), "Why are rural people vulnerable to famine?", IDS Bulletin Vol.20, No 2.
The value of CPRs to the poor is heightened because they often provide varied safety nets in the form of remunerative activity or food, at times when other opportunities are lacking.

- Scavenging: (Mainly urban) and gleaning (mainly rural), including traditional rights and access to private residues (buttermilk, crop residues as fuel etc.)

- Processing. hawking, vending and marketing: Including produce from home gardens and common property resources.

- Share-rearing of livestock: Where livestock are lent for herding in exchange for rights to some products and/or offspring.

The core of a livelihood can be expressed as a living, with people, tangible assets and intangible assets contributing to it. The tangible assets commanded by a household are stores such as food stocks, stores of value such as gold, jewellery and woven textiles. and cash savings in thrift banks and credit schemes; and resources such as land, water, trees, livestock, farm equipment, tools and domestic utensils. The intangible assets are claims which can be made for material, moral or other practical support, and access, meaning the opportunity in practice to use a resource, store or service, or to obtain information. material, technology. employment, food or income. ${ }^{(49)}$

- Transporting goods with a horse, donkey, mule, cart, bicycle, or head or backloading.

- Mutual help: Including small borrowings from relatives and neighbours.

- Contract outwork: Weaving, rolling cigarettes, making incense sticks...

- Casual labour and piecework especially in agriculture.

- Specialized occupations: Barbers, blacksmiths, carpenters, prostitutes, tailors

- Domestic service: Especially by girls and women.

- Child labour: Both domestically (collecting fuel-leaves, twigs, branches, dung, collecting fodder, weeding, herding animals, removing stones from fields and ticks from livestock...) and working in factories (making matches, candles, fireworks...), restaurants, people's houses...

- Craft work of many sorts.

- Mortgaging and selling assets, future labour and children.

- Family-splitting: Including putting out children to others.

- Migration for seasonal work in agriculture. brick-making, urban construction...

- Remittances

- Seasonal food-for-work, public works and relief.

- stinting in many ways, with food and other consumption.

- Begging

- Theft

- Triage: especially with girl children and weaklings.

... and so on.

The point of this incomplete list is to illustrate. Often, an individual or a household engages in many livelihood activities such as these over a year. This does not fit in with any concept of

Environment and Urbanization, Vol. 7, No. 1, April 1995 
50. See Chambers, Robert, Arnold Pacey and Lori Ann Thrupp (editors) (1989), Farmer First: Farmer Innovation and Agricultural Research, Intermediate Technology Publications, London; also Scoones, lan and John Thompson (editors) (1994), Beyond Farmer First: Rural People's Knowledge, Agricultural Research and Extension Practice, Intermediate Technology Publications, London.

51. Pretty, Jules N. (1995), Regenerating Agriculture : Policies and Practice for Sustainability and Self-Reliance, Earthscan, London.

52. Handy, Charles (1989), The Age of Unreason, Arrow Books, London. "employment" in "a job". Individuals and families diversify and complicate their livelihood strategies in order to increase income, reduce vulnerability and improve the quality of their lives.

A similar pattern is shown by "the third agriculture". ${ }^{(50)}$ The first, or industrial agriculture is standardized and simple and the second, or green revolution agriculture has high-yielding packages in controlled conditions. The third agriculture, which provides support for some 1.9 to 2.2 billion people is complex, diverse and risk-prone. ${ }^{(51)}$ Farmers working within complex, diverse and risk-prone farming seek to reduce risk and increase food and income by complicating, diversifying and, where labour is available, intensifying their farming systems, adding to their enterprises. They multiply the internal links and flows within their farming systems, for example through aquaculture, composting, cut-and-carry for stallfed livestock, multiple cropping, agroforestry, home-gardening, and the concentration of nutrients, soil and water in micro-environments such as silt deposit fields and protected pockets of fertility.

For these realities, of the strategies employed by most of the rural poor and many of the urban, sustainable livelihood fits better than employment as a concept. Employment, in the sense of having an employer, a job, a workplace and a wage is more widespread as an aspiration than as a reality. Where economic crisis and structural adjustment cut urban jobs, the proportion of foxes can be expected to increase. Moreover. however much poor people may seek employment and educate their children in the hope that they will find a secure and remunerative job, for most such a job is not a realistic prospect. Even in the North, the classic concept of a single employment is being challenged ${ }^{(52)}$ and portfolio, fox, livelihoods are becoming more common. Even more so in much of the South, most livelihoods of the poor will continue to be adaptive performances, improvised and versatile in the face of adverse conditions, sudden shocks and unpredictable change.

In identifying actions, then, it makes sense to shift thinking from labour intensive growth towards sustainable livelihood intensive change. This is not to argue against growth, or against a strategy of labour intensive growth: but to qualify and complement it. For labour intensity and sustainable livelihood intensity, though overlapping, are not identical. As a concept, labour intensity links with employment. A sustainable livelihood intensive strategy goes beyond employment to stress:

- Natural resources: Sustainable management of natural resources, especially common property resources, and equitable access to them for the poorer.

- Redistribution of private and public livelihood resources to the poor.

- Prices: Marketing, prices and prompt payment for what poor people sell, and terms of trade between what poor people sell and what they buy.

- Health: Accessible health services for the prevention of disease and for prompt and effective treatment of disabling accidents and disease. 
- Restrictions and hassle: Removal of restrictions on livelihood activities otherwise used to hassle and exploit the poor.

- Counter-seasonality and safety nets for poor people at bad times, mitigating seasonal stress and enabling them to conserve their livelihood assets.

To conclude, deprivation and well-being as perceived by poor people, and sustainable livelihoods as a shared goal of outsiders and the poor, question the degree of primacy often attributed to income-poverty. The realities of the poor are many and particular. They can experience and agonize over acute tradeoffs between different dimensions of deprivation and well-being. What they value and choose often differs from what outsider professionals expect. Income matters, but so too do other aspects of well-being and the quality of life - health, security, self-respect, justice, access to goods and services, family and social life, ceremonies and celebrations, creativity, the pleasures of place, season and time of day, fun, spiritual experience and love. If development means good change, it is so much more than economic growth and income; it is also these and many other aspects of well-being and quality of life, as poor people experience and wish them.

\section{THE PARADIGM OF REVERSALS: THE INSTITUTIONAL, PROFESSIONAL AND PERSONAL CHALLENGE}

ANTI-POVERTY ACTION has often been justified to the rich and powerful by appealing to enlightened selfishness: this has stressed mutual interests and the bad impacts of poverty, suffering and deprivation on those who are better off, and on the North as a whole. The strongest argument was perhaps that of the Brandt Commission, that the North had an economic interest in economic growth in the South. To the extent that reciprocal non-zero sums exist or can be found, they must be welcomed. But such arguments do not always hold up. Well-meaning casuistry about mutual interest, argued during the development decades to justify helping the poor, can prove a shifting sand. To rely on arguments about mutual material interests is to risk loss of support if they do not exist. Ethical arguments are stronger, surer and better. The prescriptions which follow are founded not on self-interest on the part of the rich and powerful, which may or may not be served, but on the values of common decency, compassion and altruism.

The differences between top-down reductionist definitions and objectives, and poor people's realities present development professionals with challenges which are institutional. professional and personal. The challenges are paradigmatic: to reverse the normal view, to upend perspectives, to see things the other way round, to soften and flatten hierarchy, to adopt downward accountability, to change behaviour, attitudes and beliefs, and to identify and implement a new agenda; in sum, to define and embrace a new professionalism. 
This new professionalism and its paradigm stress reversals, decentralization, local diversity and complexity, and empowerment.

1. The Institutional Challenge: Professionals, whether in NGOs, government departments, training institutes and universities or donor agencies, have been slow to see that the fine words "participation", "ownership" and "empowerment", by and for the poor, demand institutional change "by us". Participation "by them" will not be sustainable or strong unless we too are participatory. "Ownership" by them means non-ownership by us. Empowerment for them means disempowerment for us. In consequence, management cultures, styles of personal interaction and procedures all have to change.

One indicator of the orientation of an agency is the composition of its staff. Middle-aged economists, often Northern and male, still dominate international development organizations and the development discourse. In contrast, social anthropologists, social development advisers and psychologists remain few. Modest increases in their numbers are patchily achieved: num-

53. This guess is a form of calculated irresponsibility, calculated in the sense of being designed to provoke someone to come up with a better figure. Any better information will be appreciated, especially if accompanied by details of definition of categories, including whether supported by core or trust funds.

54. ODA increased the numbers of social development advisers from two in 1988 to 21 by mid1994.

55. Fujisaka, Sam (1994), Will Farmer Participatory Research Survive in the International Agricultural Research Centres, Gatekeeper Series No.44, International Institute for Environment and Development, London, page 10.

56. See Senge, Peter M. (1992), The Fifth Discipline: the Art and Practice of the Learning Organization, Century Business, Random House, London; see also Pretty, J.N. and Robert Chambers (1993), "Towards a learning paradigm: new professionalism and institutions for agriculture", Discussion Paper 334 , Institute of Development Studies, University of Sussex, December.

57. See reference 55 . bers of social anthropologists and sociologists working in their professional capacities for the World Bank are hard to estimate but they are outnumbered by their economist colleagues by perhaps between 20 and 50 to one. ${ }^{(53)}$ In contrast, the ratio of economists to social development advisers in the Overseas Development Administration of the British Government is of the order of three to one, ${ }^{(54)}$ still high, but dramatically lower than in the Bank. Gains in the numbers and influence of non-economist social scientists are also vulnerable. The International Potato Centre earlier demonstrated the big contributions social anthropologists could make in agricultural research but has now reduced their number. Astonishingly, the International Crops Research Centre for the Semi-Arid Tropics (ICRISAT) is reported to have no anthropologists at all. ${ }^{(55)}$ The institutional challenge for all development agencies is to become learning organizations. ${ }^{(56)}$ It is to flatten and soften hierarchy, to develop a culture of participatory management, to recruit a gender and disciplinary mix of staff committed to people, and to adopt and promote procedures, norms and rewards which permit and encourage more open-ended participation at all levels. Project procedures, textbooks and training all require revision. Topdown targets, drives to disburse funds fast, rewards for big spenders, and rushed visits, meetings and decisions have all to be restrained and reversed.

2. The Professional Challenge: The professional challenge is paradigmatic and profound. Normal professional orientations, concepts, values, methods and behaviour reinforce the dominance of the North and of whatever is industrial, capital-intensive and "sophisticated". Its magnetic force repeatedly reasserts itself. Small successes in reversing it are vulnerable to flipping back again to the norm. In the CGIAR, for instance, farmer participatory research, painstakingly established by a small number of social and natural scientists, is threatened by the current "infatuation with biotechnology as a top-down cure-all". ${ }^{(57)}$

The challenge is to learn to see things the other way round, to 
58. Conway, Gordon, Uma Lele, Jim Peacock and Martin Pineiro (1994), "Sustainable agriculture for a food secure world: a vision for international agricultural research", a statement by an external panel appointed by the CGIAR Oversight Committee of the Consultative Group on International Agricultural Research, July, page 11.

59. Chambers, Robert (1994), "All power deceives" in S. Davies (editor), "Knowledge is Power?", IDS Bulletin Vol.25, No.2, pages 14-16.

60. Leach, Melissa and James Fairhead (1994), "Natural resource management: the reproduction and use of environmental misinformation in Guinea's forest-savannah transition zone" in S. Davies (editor), "Knowledge is Power?", IDS Bulletin Vol.25 No.2, pages $81-87$

61. For a fuller statement, see "NGOs and development: the primacy of the personal" available on request from the author. The paper applies at least as much force to govemment and donor agencies as to NGOs. appreciate and grasp that other reality, of local people. In the words of the recent vision paper for the CGIAR it is "...to reverse the chain of logic, starting with the socio-economic demands of poor households ${ }^{n(58)}$ in order to identify appropriate research priorities. But such reversals are impeded by normal professionalism, by disciplinary specialization and by the nature of worldwide upper-lower interactions between those who are dominant and those who are subordinate. ${ }^{(59)}$ The stronger the dogmatism and drive of the upper (the World Bank task manager, the senior official, the knowledgeable professional...) so the more he (most are men) is likely to be misled. As with the remarkable story of the misperceived ecological history of the Guinea forest-savannah mosaic, professional and bureaucratic misbelief is perpetuated by the politeness and prudence of those who know another reality:

"Villagers, faced by questions about deforestation and environmental change, have learned to confirm what they know the questioners expect to hear. ${ }^{n(60)}$

So the prudent poor and weak perpetuate the fantasies and fallacies of the powerful and strong. All power deceives.

The professional challenge is to review and reorient normal professional concepts, values, methods and behaviour which serve "our" purposes and, instead, enable the poor to express their reality. The new professionalism entails recognizing the extent to which "our" reality is generated by our training, interactions, power and central needs, and then revising and reversing many normal concepts, values, methods and behaviours.

3. The Personal Challenge: The personal dimension is as paramount as it is perversely overlooked. ${ }^{(61)}$ Again and again, in the experience of Participatory Rural Appraisal, the behaviour and attitudes of outsiders have been the key to facilitating participation, to enabling people who are poor and weak to come together and express and analyze their reality. Yet the personal is scarcely on the development agenda at all. Psychologists and psychotherapists are rare among development professionals and, where they are found, tend to be in other than their specialized roles. It is, though, obvious to the point of embarrassment, that individual personality, perceptions, values, commitment and behaviour are crucial for institutional and professional change.

The personal challenge applies in all social spheres. It is not limited to professional work. For example, men can feel personally threatened by feminism and the focus on women in development. For these imply changes in roles and relationships both at work and at home. And they can raise ethical questions about limits to inter-cultural tolerance, as with dowry, female genital mutilation and selective abortion.

The personal challenge can be expressed as the paragon new professional. She is committed to the poor and weak and to enabling them to gain more of what they want and need. She is democratic and participatory in management style, is a good listener, embraces error and believes in failing forwards, finds pleasure in enabling others to take initiatives, monitors and

Environment and Urbanization, Vol. 7, No. 1, April 1995 
controls only a core minimum of standards and activities, is not threatened by the unforeseeable. does not demand targets for disbursements and achievements, abjures punitive management. devolves authority expecting her staff to use their own best judgement at all times, gives priority to the front-line, and rewards honesty. For her, watchwords are truth, trust and diversity. And throughout this paragraph she can also be a he.

Much of the challenge is to give up power. It is to enjoy handing over the initiative to others, enabling them to do more and to do it more in their way, for their objectives. This has its own satisfactions, in seeing how well and how differently people do things and what they achieve. The need is for those with power to learn to value and enjoy these satisfactions.

\section{WELL-BEING AND LIVELIHOODS: IMPLICATIONS FOR POLICY AND PRACTICE}

THIS ANALYSIS REFRAMES and shifts the balance of objectives of development: from reducing income-poverty to diminishing deprivation and enhancing well-being; and from increasing employment to sustaining livelihood. Development then demands and generates diversity, as deprivation is so much more than lack of income, livelihood is so multifarious and dynamic, and well-being as people experience and desire it has so many dimensions. Equity also applies but now more to what poor people themselves define as priorities and strategies, and less to what we suppose they ought to want.

To support and achieve these objectives there are two agendas: one with elements that are current and familiar even it is often convenient to overlook parts of it; and a new one based on the paradigm of reversals. For completeness, both are presented but the first in brief.

1. A Current Agenda: An updated and amended current agenda overlaps with, qualifies and adds to the two-legged orthodoxy of the World Bank of labour intensive growth and basic

62. World Bank (1990), World Development Report 1990 , Oxford University Press, Oxford. services with its add-on of safety nets. ${ }^{(62)}$ This agenda includes:

$i$ Peace and equitable law and order. these have primacy as pre-conditions for sustainable weli-being. The horrors of Rwanda are an extreme example and civil disorder has spread since the end of the Cold War. Much more widespread is the lack of the equitable rule of law to provide justice for the poor and powerless.

ii. International terms of trade: given the dominance of greed and selfishness in the Western democracies, it is unlikely that anything much will be done about this until powerful people change and exercise extraordinary leadership. This requires altruism, meaning that the powerful must value non-material rewards and act against their own narrowly defined material interests for the sake of others.

iii. Debt relief and good aid to debtor countries (but not including the United States or other rich debtors). The need for these is so widely recognized that no more will be said.

iv. Domestic macro-economic policy: this includes livelihood 
intensive growth. Domestic macro-policy in all countries should be informed more by the realities of the poor as they experience and express them, and less by the realities supposed for the poor by the powerful. Few would now deny that, had structural adjustment programmes been oriented in this manner from the start, much suffering would have been averted.

$v$. Redistribution: redistributive policies from the rich to the poor, whether through assets such as land or through taxation, deserve revival and restoration from the limbo to which neoclassical orthodoxy has consigned them. Redistribution, for example of land, has been found again and again to be efficient as well as equitable.

vi. Rights and information: the poorer people are, the more they need, and can gain from, secure rights and information about those rights. This includes the credible abolition of rules and restrictions which empower officials to extort bribes, and organization and legal support to ensure effective justice.

vii. Infrastructure and access to basic services: this includes health, education, water, transport, credit and marketing. These are well recognized but access by the poor remains crucial and is often neglected and weak or non-existent in practice.

viii. Access to affordable basic goods: the ILO basic needs list did not include access to affordable basic goods yet they matter much to poor people and are quite often beyond their reach, especially those who are rural and more remote from urban centres.

ix. Safety nets: safety nets, the third, sometimes lame, policy leg of the World Development Report (1990) are vital for many of the poor. ${ }^{(63)}$ Food-for-work and famine relief often come too late, after people have lost or been forced to dispose of livelihood assets. Some professionals and organizations still see food aid only as famine relief and not as a livelihood-sustaining safety net to help poor people avoid becoming poorer. For sustainable livelihoods, the vulnerable poor need safety nets.

2. Reversals and Altruism: the New Agenda: The new paradigm is people centred, participatory. empowering and sustainable. These nice words are more deeply embedded in the reflexes of paper and speech-writers than in the mental frames and personal behaviour of those who write the papers and read out the speeches. For the paradigm demands reorientation, an upending of much of the normal upper-lower, North-South dominance. It combines reversals and altruism: reversals to stand the norm on its head, to see things the other way round, to enable the poor and weak to express their reality, and to put that reality first; and then altruism, to act in the interests of the poor and powerless. The paradigm of reversals and altruism stands as a challenge for the Social Development Summit.

The reversal of logic is fundamental. Instead of starting with the analysis of central professionals, the logic starts with the realities of the peripheral poor. Policy is not deduced and driven centre-outwards, with distant assumptions about effects on the poor, but induced and drawn up from the experience and analysis of those who live local realities and know what happens close to them. Nor is the argument that this should be the only logic:

Environment and Urbanization, Vol. 7, No. 1, April 1995 
64. Freire, Paulo (1970), Pedagogy of the Oppressed, The Seabury Press, New York. See also: Korten, David C. and Rudi Klauss (editors) (1984), PeopleCentered Development: Contributions toward Theory and Planning Frameworks, Kumarian Press, West Hartford, Connecticut, USA; Cernea, Michael, (editor) (1991), Putting People First: Sociological Variables in Rural Development, second edition, Oxford University Press for the World Bank; Burkey, Stan (1993), People First: a Guide to Self-reliant, Participatory Rural Development, Zed Books, London and New Jersey.

65. Mascarenhas, James, et al. (1991), "Participatory rural appraisal: proceedings of the February 1991 Bangalore PRA Trainers Workshop", RRA Notes 13, IIED, London and MYRADA, Bangalore, August; Chambers, Robert (1994) "The origins and practice of participatory rural appraisal," World Development Vol.22, No.8, July, pages 953 969. See also Chambers, Robert (1994), "Participatory rural appraisal (PRA): analysis of experience", World Development Vol.22, No.9, September, pages 1253-1268; Chambers, Robert (1994), "Participatory rural appraisal (PRA): challenges, potentials and paradigms", World Development Vol.22, No.10, October, pages 1437-1454; and Stewart, Sheelagh et al. (1994), Participatory Rural Appraisal: Abstracts of Selected Sources, Institute of Development Studies, University of Sussex, Brighton. For further sources, see Stewart et al. as before.

66. Welbourn, Alice (1991), "RRA and the analysis of difference", RRA Notes 14, pages 14-23.

\section{See reference 29}

68. Personal communication Charity Kabutha and Deepa Narayan. it is complementary. But the scales are so weighted against it that, unless it is put first and kept first, nothing like a good balance and mix of logics will ever be achieved.

A key point for healthy sceptics is the cost-effectiveness of this agenda. Good things which poor people want and which have not been done because they have not been recognized can have high pay-offs. Many measures which make a big difference to poor people have low financial costs. Rights, security, the rule of law, information, access, changes in procedures, removals of restrictions, polite behaviour by officials, timing actions for the right season, timely delivery, providing diverse "baskets of choices" (of crop varieties, trees, uses of credit and so on) - these are examples of actions which can have low financial costs and high benefits to well-being. The key is identifying such measures and then implementing them.

The paradigm of the new agenda has four pillars. Each will be illustrated with a few of its potential practical implications.

i. Analysis and action by local people. and putting first the priorities of the poor. central to the paradigm is the basic human right of poor people to conduct their own analysis. People centred development starts not with analysis by the powerful and dominant outsiders - the "North", uppers and professionals, but with enabling local people, especially the poor, to conduct theirs. ${ }^{(64)}$ In the past five years innovations in approach and methods, some of them known as participatory rural appraisal (PRA), have contributed a new repertoire which has proved powerful and popular, when well used, in enabling poor people and communities to undertake their own appraisal, analysis and action. ${ }^{(65)}$

Putting first the priorities of the poor can refer to whole communities which are poor but equally to those who are disadvantaged - the poor, weak and marginalized, whether women or a social or economic group - within communities. To find, convene and facilitate groups of the disadvantaged demands commitment to the analysis of difference. ${ }^{(66)}$ The outcomes can include awareness and action by these groups, joint action with outside agencies and feedback into policy.

PRA approaches and methods are now being used in over 40 countries with a wide range of applications including natural resource management, agriculture, health and nutrition, and poverty programmes. PRA methods have been used in participatory poverty assessments (PPAs) sponsored by the World Bank and bilateral donors in Ghana, Zambia ${ }^{(67)}$ and Kenya ${ }^{(68)}$ enabling poor rural and urban people to analyze their conditions and to express their own values, definitions of well-being and priorities, in short, to present their realities.

Some practical implications are:

- Experiential training: those with experience in participatory approaches and training are mainly in NGOs. The spread of PRA and similar approaches requires special field based training which is still in short supply for both NGOs and government. The multiplication, personal development and deploy- 
69. For other practical implications, see Maxwell, Simon (1994), "Food security : a postmodern perspective", Working Paper 9, Institute of Development Studies, University of Sussex, October; see also reference 2.

70. Chambers, Robert, Tushaar Shah and N.C. Saxena, (1989), To The Hands of the Poor: Water and Trees, Oxford and IBH, New Delhi and Intermediate Technology Publications, London.

71. World Bank (1992), Effective implementation: Key to Development Impact (the Wapenhans Report), World Bank, Washington DC. ment of good trainers is a key to realizing the potential of participatory approaches.

- Local priorities and practice: putting people first, and poor people first of all, generates local priorities requiring local differentiation. PRA-type approaches and methods can thus reinforce and support decentralization and local diversity.

- Participatory poverty assessments and policy: PPAs give potential for poor people's problems and priorities, and their definitions of well-being, to have direct impact on national policy.

ii. Sustainable livelihoods: economic growth usually generates niches for new or enhanced and diversified livelihoods, and the resources for services. But economic growth can also destroy livelihoods. Policies can also be livelihood intensive without economic growth. To search for and implement livelihood-generating and supporting policies is a priority. It is especially so in countries where economic growth is difficult. Some practical implications are: ${ }^{(69)}$

- Secure rights: secure rights to land, water and trees encourage and support long-term investment by families. Secure rights to common property resources provide a basis for sustainable management by communities. Secure rights of ownership, access and use are fundamental to the sustainability of livelihoods which rely on natural resources.

- Removal of restrictions which hamper and harm: for example, effective removal of restrictions on urban informal sector activities can reduce the insecurity, anxiety and humiliation of poor artisans, vendors and entrepreneurs, and the petty rents they otherwise have to pay to officials. Or abolishing restrictions on the cutting and transport of trees from private land increases farm-gate values for trees, encourages tree planting and protection and so enhances livelihood security by allowing trees to become savings banks for small and poor farmers. ${ }^{(70)}$

- Access to effective health services: the livelihoods of most poor people depend on their bodies. Health and quick, effective treatment, especially for disabling accidents and sickness, matter more to them than to the less poor. A livelihood cannot be sustained if its main asset is the body, and that is sick, damaged or disabled. Health services for prevention and prompt and effective treatment of accidents and sickness, and for rapid recovery, are basic for sustainable livelihoods for the poor.

iii. The three Ds: decentralization, democracy and diversity: reversals require decentralization with transfers of power and democratic modes of operation. Together, these make space for diversity and local fit of action to need. The basic principle is that of subsidiarity, that every activity should be carried out as low down as feasible. Complementing this, ownership and accountability are reframed.

Ownership shifts downwards. At a high level, this was presaged in the World Bank's Wapenhans Report "Effective Implementation: Key to Development Impact ${ }^{m(71)}$ which recommended

Environment and Urbanization, Vol. 7, No. 1, April 1995 


\section{See reference 15.}

73. World Bank (1994), The World Bank and Participation, Report of the Learning Group on Participatory Development, fourth draft, April 28, 1994.

74. World Bank (1994), The World Bank and Participation, Operations Policy Department, World Bank, Washington DC, September.

75. See reference 73, page 2. a shift of ownership from Washington to national capitals; in the Bank's response ${ }^{(72)}$ which endorses partnership and participation; in the Report of the Participation Learning Group of the Bank $^{(73)}$ which outlined and recommended practical actions for the participation of the poor; and in the final publication which followed, The World Bank and Participation ${ }^{(74)}$ which presented an agreed action plan by the Bank. The implication for all development organizations is that at every level ownership is pushed down. handed over and fostered. Beyond this, participation at the community or group level is then not "their" participation in "our" programme but our participation in theirs; and participation by the poor is not only in the design and implementation phases of projects but also in identification, monitoring and evaluation, and policy formulation.

Accountability is reversed. Downward accountability is to the poor and weak. It is to those who have been described in the World Bank as "primary stakeholders: those expected to benefit from, or be adversely affected by, Bank supported operations, particularly the poor and marginalized". ${ }^{(75)}$ So professionals are responsible to their clients: health workers to the sick, agricultural researchers and extensionists to farmers, NGO workers and officials (whether national or foreign, local or central) to poor villagers, slum dwellers and others among the primary stakeholders who are or might be touched by their decisions and actions.

Some practical implications are:

- Procedures: many procedures for central control impede decentralization and diversity. In the World Bank, for example, changes made or contemplated in the legal framework, and procedures for procurement and disbursement, will support decentralization, subsidiarity and participation.

- Appraisal, action, monitoring and evaluation: these all shift downwards and become more participatory and more diverse. In particular, poor people and communities conduct their own monitoring and evaluation, using their own baselines and indicators to reflect their own concepts of ill-being and wellbeing and their insights into causality, enhancing their understanding and ownership, and holding agencies to account. Poor people then monitor and evaluate the programmes and actions of development professionals and organizations.

iv. Professional and personal change: the key to the new agenda is as obvious as it is neglected. To an extraordinary degree, we development professionals abstain from looking at ourselves as people. The subject is almost taboo. Yet who we are, where we go, how we behave, what we are shown and see, how we learn, are deceived, and deceive ourselves, the concepts we use, the language we speak, what we believe and, above all, what we do and do not do - these so obviously affect all other aspects of development and development policy. It is bizarre that psychology, psychotherapy and management learning scarcely exist in development studies or practice. As a matter not of evangelism but of analytical rigour, it would seem that it is we the profes- 
76. See Pretty and Chambers (1993), reference 56.

77. Kochendorfer-Lucius, $G$. and K. Osner (1991), Development Has Got a Face: Life Stories of Thirteen Women in Bangladesh on People's Economy. Results of the international Exposure and Dialogue Programme of the German Commission of Justice and Peace and Grameen Bank in Bangladesh, October 14-22 1989, Gerechtigkeit und Frieden series, Deutsche Kommission Justitia et Pax, Kaiserstrasse 163, D-5300 Bonn 1; also Osner, Karl. Gudrun KochendorferLucius, Ulrika Muller-Glodde and Claudia Warning (1992) Exposure und Dialogprogramme: Eine Handreichnung fur Teilnahme und Organisatoren, Justitia et Pax, Kaiserstrasse 163,5300 Bonn 1. sionals, the powerful and the influential, and those who attend roundtables and summits, who have to reconstruct our realities, to change as people, and enable and empower others to change, if the new paradigm of development is to prevail.

Some practical implications are:

- More participatory management in deveispment organizations, including multilateral and bilateral agencies, NGOs both Northern and Southern, research institutes, training colleges and institutes, government departments in headquarters and in the field, and universities, entailing the adoption of participatory personal styles and interactions.

- Interactive learning(76) to replace unidirectional lecturing and teaching as approach and method, both in teaching and training institutes and in universities and colleges. This entails a shift from top-down teaching to learning which is shared, lateral and experiential.

- Experiential learning from poor people, meaning that those who are powerful step down, sit, listen and learn. One initiative is the German Dialogue and Exposure Programme in which senior politicians, officials and academics engage in unhurried learning in the field from individual poor families. ${ }^{(77)}$ PRA also has been a means to enable outsiders to facilitate and gain insight from the analysis of poor local people both rural and urban. The practical implication is that agencies authoritatively set aside time for field experiential learning for their staff so that they, directly, as people, can see, hear and understand that other reality, of poor people, and then work to make it count.

\section{Whose Reality will count at the Social Development Summit?}

In its concern with poverty and employment, the Social Development Summit may be in danger of plodding in worthy but well worn ruts which lead nowhere new. The challenge is to go beyond the normal agenda: beyond poverty to well-being, and beyond employment to sustainable livelihoods. It is to explore the new paradigm, to embrace the new professionalism and to concern itself with whose reality counts. To justify the cost, time and effort of the Summit, to make things better for the poor, it will have to question conventional concepts of development; to challenge "us" to change, personally, professionally and institutionally; and to change the paradigm of the development enterprise. If the poor and weak are not to see the Summit as a celebration of hypocrisy, signifying not sustainable well-being for them but sustainable privilege for us, the key is to enable them to express their reality, to put that reality first and to make it count. To do that demands altruism, insight, vision and guts. Will these qualities show at the Summit? Is there hope that the reality that counts at the Summit will be not ours but that of the poor?

Environment and Urbanization, Vol. 7, No. 1, April 1995 